\title{
Weed Management in Maize System in New Alluvial Zone of West Bengal, India
}

\author{
Sonali Biswas $^{1 *}$, Srabani Debnath ${ }^{2}$, Abhijit Saha ${ }^{3}$ and Benukar Biswas ${ }^{4}$ \\ ${ }^{1}$ Department of Agronomy, AICRP on Maize, Directorate of Research, Bidhan Chandra \\ Krishi Viswavidyalaya, Kalyani, Nadia-741235, West Bengal, India \\ ${ }^{2}$ Department of Pathology, AICRP on Maize, Directorate of Research, Bidhan Chandra Krishi \\ Viswa vidyalaya, Nadia, West Bengal, India \\ ${ }^{3}$ Department of Agronomy, College of Agriculture, Lembucherra, West Tripura, \\ Tripura, India \\ ${ }^{4}$ Department of Agronomy, Department of Agronomy, Bidhan Chandra Krishi Viswa \\ vidyalaya, Nadia, West Bengal, India \\ *Corresponding author
}

\begin{abstract}
A B S T R A C T
A field experiment was conducted to evaluate the options of best weed management practices in maize-wheat cropping system during kharif season, 2015 and 2016 at the District seed farm, (AB Block), Kalyani, Bidhan Chanra Krishi Viswavidalaya, Nadia, and West Bengal. In maize field, lowest number of weeds per $\mathrm{m}^{2}$ and weed dry weight per $\mathrm{m}^{2}$

\section{Keywords}

Maize, Grain yield, Weed management, Net return

\section{Article Info}

Accepted:

12 March 2018

Available Online:

10 April 2018 were observed in weed free check and significantly lower number of weeds per $\mathrm{m}^{2}$ and weed dry weight per $\mathrm{m}^{2}$ were obtained with pre-emergence application of Atrazine @ 1.5 $\mathrm{kg}$ a.i/ha fb (followed by) Tembotrione (Laudis) $120 \mathrm{~g}$ a.i/ha POE (post emergence) at 25 DAS ( $\mathrm{T}_{10}$ treatment) which was statistically at par with $\mathrm{T}_{9}$ treatment (pre-emergence application of pendimetalin @ $1000 \mathrm{ml} / \mathrm{ha}$ fb Atrazine @ $750 \mathrm{~g} \mathrm{a.i} / \mathrm{ha}+2$, 4-D Amine @ $0.4 \mathrm{~kg}$ a.i/ha at $25 \mathrm{DAS}$ ) as POE during the both years. During both the years, it was observed that highest maize grain yield, cob yield and system productivity in term of maize equivalent yield were obtained in weed free check which was statistically at par with treatment receiving Atrazine @ $1.5 \mathrm{~kg}$ a.i/ha fb Tembotrione (Laudis) $120 \mathrm{~g}$ a.i/ha POE at 25 DAS during first year of experimentation and which was closely followed during second year of experimentation. During the first year of experimentation (2015) highest net return and $\mathrm{B}$ : $\mathrm{C}$ ratio was obtained in treatment $\mathrm{T}_{9}$ which was at par with $\mathrm{T}_{10}$ treatment. During second year of experimentation (2016) highest net return (Rs.100043/-) was recorded in weed free check followed by sequential application of Atrazine @ $1.5 \mathrm{~kg}$ a.i/ha as pre emergence fb Laudis $120 \mathrm{~g}$ a.i/ha as POE application (96,452/-).
\end{abstract}

\section{Introduction}

Maize (Zea mays L.) is one of the most important among the cereal crops in the world agricultural economy both as food and fodder crop and is regarded as queen of cereals. It is one of the most versatile cereal crops having wider adaptability under diverse soil and climatic condition. In India, productivity of maize is low as compared to world which can 
be attributed to several limiting factors and all but the most important amongst these has been the poor weed management which poses a major threat to crop productivity. Maize being a wider spaced crop with slow early growth, favours the growth of weeds even before crop emergence. Presence of weeds reduces the photosynthetic efficiency, dry matter production and distribution to economical parts and there by reduces sink capacity of crop resulting in poor grain yield. In India, the presence of weeds, in general reduces the maize yield by $27-60 \%$, depending upon the growth and persistence of weed population in maize crop (Tripathi et al., 2005, Jat et al., 2012, Singh et al., 2015, Kumar et al., 2012).

Porwal (2000) observed that in the rainy season, emergence of maize and weeds were simultaneous and found that the first 20-30 days were the most critical period of competition for the crop. During this critical period weeding is essentially required by chemical and non-chemical means. Weeding by hand (labour) and mechanical means are expensive, time consuming, labour intensive and many a times timely operations are not possible due to continuous rains in monsoon season.

Herbicides are one of the crucial factors in a worldwide increase in cereal production. Clearly the farmer using herbicides in maize production is saving money or effort on mechanical weed control. There is an environmental benefit too in reduced use of fossil fuels and reduced soil disturbance in no till system representing a common benefit to us all. There are different categories of herbicides used in maize/maize based cropping system to manage weeds based on the time of application of herbicides viz. pre emergence herbicides, early post-emergence and post-emergence herbicides. Usage of preemergence herbicides assumes greater importance in the view of their effectiveness from initial stages. Atrazine, pendimethalin, alachlor and oxadiargyl are some of the mostly used pre-emergence herbicides applied in maize based systems.

Atrazine and other herbicides recommended as a pre-emergence herbicides, is not effective against some of the weeds, both grassy and non-grassy as well as the sedges. Also, sometimes farmers skip the application of preemergent herbicides and also due to the scarcity of labour at that time, there is left no other alternative to control the weeds emerging during later stages. However, recently a pigment synthesis inhibitor tembotrione, which is post-emergent broad spectrum systemic herbicide of triketone group has been tested and proved to successful in managing all the categories of weeds infesting the maize field during the later stages (Singh et al., 2012) and also increasing the yield of crop succeeding season (wheat) due to herbicides residue left over and ultimately reducing the pollution hazard. So, the present investigation was carried out to find out the best promising herbicide/herbicides combination to control all kinds of weeds in maize and their effect on succeeding wheat crop grown under sequential cropping.

\section{Materials and Methods}

A field experiment was conducted during kharif and rabi seasons of 2015-16 and 201617 in maize-wheat cropping sequence at the district seed farm, (AB Block), Kalyani, Bidhan Chanra Krishi Viswavidalaya, Nadia, West Bengal. The site situated at an attitude of about $9.75 \mathrm{~m}$ above mean sea level at $22^{\circ} 57^{\prime} \mathrm{N}$ latitude and $88^{\circ} 20^{\prime} \mathrm{E}$ longitude. The soil was silty clay loam in texture having $\mathrm{pH} 7.32$, medium in organic carbon $(0.53 \%)$, available $\mathrm{N} 145.28 \mathrm{~kg} / \mathrm{ha}$, available $\mathrm{P} 28.82 \mathrm{~kg} / \mathrm{ha}$ and available $\mathrm{K} 282.24 \mathrm{~kg} / \mathrm{ha}$. The experiment was laid down in RBD design with three replication and consists of ten (10) weed 
management practices viz. $\mathrm{T}_{1}$ :Control (weedy check), $\mathrm{T}_{2}$ : Weed free, $\mathrm{T}_{3}$ : Atrazine @ $1.5 \mathrm{~kg}$ a.i/ha as pre-emergence, $\mathrm{T}_{4}$ : Atrazine $(750 \mathrm{~g}$ a.i /ha) + pendimethalin ( $750 \mathrm{ml} \mathrm{a.i/ha)} \mathrm{as} \mathrm{pre-}$ emergence, $\mathrm{T}_{5}$ : Atrazine (1.5 kg a.i/ha) preemergence fb 2,4-D Amine (400 ml a.i/ha) at 25 DAS as post emergence, $\mathrm{T}_{6}$ : Halosulfuron (a) $90 \mathrm{~g} / \mathrm{ha}$ at $25 \mathrm{DAS}, \mathrm{T}_{7}$ : Atrazine $(1.5 \mathrm{~kg}$ a.i/ha) pre-emergence $\mathrm{fb}$ Halosulfuron (90 $\mathrm{g} / \mathrm{ha}$ ) at 25 DAS as post emergence, $\mathrm{T}_{8}$ : Tembotrione $(120 \mathrm{ml} \mathrm{a.i/ha)}$ at $25 \mathrm{DAS}$ as post emergence, $\mathrm{T}_{9}$ : Pendimethalin $(1000 \mathrm{ml}$ a.i/ha) pre-emergence $\mathrm{fb}$ Atrazine (750 g a.i/ha) + 2,4-D Amine (400 ml a.i/ha) at 25 DAS as post emergence and $\mathrm{T}_{10}$ : Atrazine (1.5 $\mathrm{kg}$ a.i/ha) pre-emergence $\mathrm{fb}$ Tembotrione (120 $\mathrm{ml}$ a.i/ha) at 25 DAS as post emergence. Maize variety $\mathrm{P} 3377$ was sown manually at spacing of $60 \mathrm{~cm} \times 20 \mathrm{~cm}$ using $20 \mathrm{~kg}$ seed /ha in (2015 and 2016), respectively and fertilizer with 150:60:60 (N, $\mathrm{P}_{2} \mathrm{O}_{5}$ and $\left.\mathrm{K}_{2} \mathrm{O} \mathrm{kg} / \mathrm{ha}\right)$. Both $\mathrm{P}$ and $\mathrm{K}$ and $1 / 3$ dose of Nitrogen were applied at the time of sowing and remaining $\mathrm{N}$ was applied in two equal splits doses at knee height and tasseling stages. Herbicidal treatments were applied as per treatments and spraying was done with the help of Knapsack sprayer fitted with a flat fan nozzle with the spray volume of water $600 \mathrm{ml} / \mathrm{ha}$. Weed population was taken by quadrate method and dry weight was done as per standard method. The density and weed dry weight were analyzed after subjecting the original data to square root transformation $[\sqrt{\mathrm{x}+0.5}]$. The treatment effects were compared using transformed means.

The succeeding wheat crop variety PBW 343 was sown on middle of November during both the years of study (2015 and 2016), respectively. The wheat crop was fertilized with 40:60: $40\left(\mathrm{~N}, \mathrm{P}_{2} \mathrm{O}_{5}\right.$ and $\left.\mathrm{K}_{2} 0 \mathrm{~kg} / \mathrm{ha}\right)$ at sowing and remaining $40 \mathrm{~kg} \mathrm{~N} / \mathrm{ha}$ was top dressed in two equal doses at CRI and flowering stages. All other practices were followed as per recommendations for wheat.
System productivity in term of maize equivalent yield was calculated by adding the grain yield of maize with maize equivalent yield of wheat calculated by using the following formula:

Total price of produce to be compared Maize equivalence $(\mathrm{Kg} / \mathrm{ha})=$

$$
\text { Price of maize } \mathrm{kg}^{-1}
$$

The yield parameters and yields were recorded and analyzed as per Gomez and Gomez (1984). The treatment comparisons were made using t-test at $5 \%$ level of significance. The economies were calculated on the basis of prevailing local market price of maize grains and cost of inputs.

\section{Results and Discussion}

\section{Effect on weed population and weed dry weight}

The weed population and dry weight of weeds in maize (Table 1) significantly reduced in the herbicide treatments. The data on weed count and dry weight revealed that, lowest weed number and weed dry weight was observed in weed free treatment but highest weed population and dry weight of weeds recorded in weedy check. Among weed management, significantly lower weeds population and dry matter production of weeds were recorded with pre-emergence application of atrazine @ $1.5 \mathrm{~kg}$ a.i/ha fb Tembotrione (Laudis) $120 \mathrm{~g}$ a.i/ha as POE at 25 DAS which was statistically at par with $\mathrm{T}_{9}$ treatment (preemergence application of pendimetalin @ $1000 \mathrm{ml} / \mathrm{ha} \mathrm{fb}$ atrazine @ $750 \mathrm{~g}$ a.i/ha +2, 4-D Amine@0.4 kg a.i/ha at 25 DAS as post emergence application). It may be due to the lowest population of grassy and non-grassy weeds in this treatment. Singh et al., found most effective to control the grassy as well as non-grassy weeds as compared to other herbicidal treatments. 
Int.J.Curr.Microbiol.App.Sci (2018) 7(4): 1344-1350

Table.1 Effect of weed management on yield and system productivity

\begin{tabular}{|c|c|c|c|c|c|c|c|c|}
\hline \multirow[t]{2}{*}{ Treatment } & \multicolumn{2}{|c|}{$\begin{array}{c}\text { Maize grain yield } \\
\text { (kg/ha) }\end{array}$} & \multicolumn{2}{|c|}{$\begin{array}{c}\text { Cob Yield } \\
\text { (kg/ha) }\end{array}$} & \multicolumn{2}{|c|}{ Wheat Yield (kg/ha) } & \multicolumn{2}{|c|}{$\begin{array}{c}\text { System Productivity } \\
\text { (kg/ha) }\end{array}$} \\
\hline & 2015 & 2016 & 2015 & 2016 & 2015 & 2016 & 2015 & 2016 \\
\hline $\mathbf{T}_{1}$ & 2525 & 7061 & 8300 & 7965 & 1444.3 & 3445.67 & 4191.5 & 11421.96 \\
\hline $\mathbf{T}_{2}$ & 4135 & 11829 & 21120 & 12735 & 3011.3 & 6031.00 & 7609.2 & 16478.67 \\
\hline $\mathbf{T}_{3}$ & 3704 & 7197 & 19769 & 8072 & 1767.3 & 4177.00 & 5743.2 & 12417.91 \\
\hline $\mathbf{T}_{4}$ & 3525 & 7183 & 18896 & 8147 & 1573.0 & 4237.67 & 5340 & 12479.86 \\
\hline $\mathbf{T}_{5}$ & 3672 & 7670 & 20281 & 8539 & 1666.3 & 4394.67 & 5594.7 & 1310.72 \\
\hline$T_{6}$ & 2734 & 7107 & 11329 & 7967 & 1799.7 & 3494 & 4810.5 & 11474.37 \\
\hline $\mathbf{T}_{7}$ & 3806 & 7201 & 20314 & 8096 & 1504.3 & 3999.33 & 5541.8 & 12199.72 \\
\hline $\mathbf{T}_{8}$ & 3284 & 7308 & 17813 & 8156 & 1817.7 & 4374.33 & 5381.3 & 12775.82 \\
\hline$T_{9}$ & 3889 & 11370 & 22385 & 12367 & 2566.3 & 4936 & 6850.2 & 14610.33 \\
\hline $\mathbf{T}_{10}$ & 3969 & 11529 & 22154 & 12514 & 2699.3 & 5463 & 7030.6 & 15623.33 \\
\hline $\mathrm{CD}(\mathrm{p}=0.05)$ & 213 & 162.6 & 263 & 132.8 & 613.34 & 543 & 688.39 & 832.46 \\
\hline
\end{tabular}

Table.2 Effect of weed management on economics

\begin{tabular}{|c|}
\hline Treatments \\
\hline $\mathbf{T}_{1}$ \\
\hline $\mathbf{T}_{2}$ \\
\hline $\mathbf{T}_{3}$ \\
\hline $\mathbf{T}_{4}$ \\
\hline $\mathbf{T}_{5}$ \\
\hline $\mathbf{T}_{6}$ \\
\hline $\mathbf{T}_{7}$ \\
\hline $\mathbf{T}_{8}$ \\
\hline $\mathbf{T}_{9}$ \\
\hline $\mathbf{T}_{10}$ \\
\hline $\mathrm{CD}(\mathbf{p}=0.05)$ \\
\hline
\end{tabular}

\begin{tabular}{|c|c|c|c|}
\hline \multicolumn{2}{|c|}{ Net Return (Rs./ha) } & \multicolumn{2}{|c|}{ B:C ratio } \\
\hline $\mathbf{2 0 1 5}$ & $\mathbf{2 0 1 6}$ & $\mathbf{2 0 1 5}$ & $\mathbf{2 0 1 6}$ \\
\hline 8300 & 42838 & 1.40 & 2.02 \\
\hline 21120 & 100043 & 1.74 & 3.38 \\
\hline 19769 & 45540 & 1.80 & 2.07 \\
\hline 18896 & 44293 & 1.81 & 2.05 \\
\hline 20281 & 50143 & 1.85 & 2.19 \\
\hline 11329 & 43382 & 1.53 & 2.03 \\
\hline 20314 & 44507 & 1.80 & 2.06 \\
\hline 17813 & 45795 & 1.82 & 2.09 \\
\hline 22385 & 94544 & 1.92 & 3.25 \\
\hline 22154 & 96452 & 1.87 & 3.30 \\
\hline & 2302.1 & & 0.1 \\
\hline
\end{tabular}


Int.J.Curr.Microbiol.App.Sci (2018) 7(4): 1344-1350

Table.3 Effect of weed management on weed population and weed dry weight during 2015

\begin{tabular}{|c|c|c|c|c|c|c|}
\hline \multirow[t]{2}{*}{ Treatments } & \multicolumn{3}{|c|}{ No. of weeds / $\mathrm{m}^{2}$ at harvest } & \multicolumn{3}{|c|}{ Weed dry weight / $\mathrm{m}^{2}$ at harvest (g) } \\
\hline & Grass & Sedge & BLW & Grass & Sedge & BLW \\
\hline $\mathbf{T}_{1}$ & $233.83(15.31)$ & $169(13.01)$ & $116.7(10.82)$ & $27.55(5.30)$ & $19.16(4.43)$ & $16.61(4.13)$ \\
\hline $\mathbf{T}_{2}$ & $0.0(0.71)$ & $0.0(0.71)$ & $0.0(0.71)$ & $0.0(0.71)$ & $0.0(0.71)$ & $0.0(0.71)$ \\
\hline $\mathbf{T}_{3}$ & $94.67(9.74)$ & $87.33(9.35)$ & $62.4(7.91)$ & $12.27(3.57)$ & $10.67(3.33)$ & $7.13(2.76)$ \\
\hline $\mathbf{T}_{4}$ & $110.33(10.52)$ & $97.66(9.88)$ & $63.3(7.98)$ & $14.35(3.85)$ & $11.56(3.46)$ & $8.15(2.93)$ \\
\hline $\mathbf{T}_{5}$ & $112.67(10.63)$ & $98.0(9.92)$ & $62.4(7.92)$ & $15.03(3.93)$ & $11.71(3.48)$ & $8.05(2.92)$ \\
\hline $\mathbf{T}_{6}$ & $152.5(12.36)$ & $109.0(10.45)$ & $109.2(10.46)$ & $17.69(4.26)$ & $13.81(3.78)$ & $14.07(3.82)$ \\
\hline $\mathbf{T}_{7}$ & $90.67(9.54)$ & $93.66(9.70)$ & $65.4(8.10)$ & $12.61(3.62)$ & $11.68(3.49)$ & $8.91(3.06)$ \\
\hline $\mathbf{T}_{8}$ & 109.67 (10.49) & $107.33(10.37)$ & $71.4(8.44)$ & $15.03(3.94)$ & $12.40(3.59)$ & $8.89(3.06)$ \\
\hline $\mathbf{T}_{9}$ & $95.83(9.80)$ & $92.33(9.63)$ & $64.8(8.08)$ & $13.72(3.77)$ & $11.58(3.46)$ & $8.44(2.98)$ \\
\hline $\mathrm{T}_{10}$ & $86.5(9.32)$ & $83.33(9.15)$ & $51.3(7.19)$ & $11.17(3.41)$ & $10.09(3.25)$ & $6.36(2.61)$ \\
\hline $\begin{array}{c}\text { CD } \\
(p=0.05)\end{array}$ & 0.86 & 1.07 & 1.06 & 0.33 & 0.5 & 0.4 \\
\hline
\end{tabular}

The data were transformed before statistical analysis using square root transformation $[\sqrt{x}+0.5]$. Figures in parenthesis are the original value for respective data.

Table.4 Effect of weed management on weed population and weed dry weight during 2016

\begin{tabular}{|c|c|c|c|c|c|c|}
\hline Treatment & $\begin{array}{c}\text { No of } \\
\text { grass } / \mathrm{m}^{2} \text { (At } \\
\text { harvest) }\end{array}$ & $\begin{array}{c}\text { No of } \\
\text { sedges } / \mathrm{m}^{2} \\
\text { (At } \\
\text { Harvest) }\end{array}$ & $\begin{array}{c}\text { No of } \\
\text { broadleaves/ } \\
\text { m }^{2} \text { (At } \\
\text { Harvest) }\end{array}$ & $\begin{array}{l}\text { Dry weight of } \\
\text { grassy } \\
\text { weeds/m² (At } \\
\text { Harvest) }\end{array}$ & $\begin{array}{l}\text { Dry weight of } \\
\text { sedges } / \mathbf{m}^{2} \text { (At } \\
\text { Harvest) }\end{array}$ & $\begin{array}{l}\text { Dry weight of } \\
\text { broadleaf } / \mathrm{m}^{2} \\
\text { (At Harvest) }\end{array}$ \\
\hline$T_{1}$ & $13.2(173.9)$ & $10.2(103.3)$ & 7.3(53.3) & 7.8(59.8) & $4.1(16.5)$ & $3.7(13.2)$ \\
\hline$T_{2}$ & $0.7(0.0)$ & $0.7(0.0)$ & $0.7(0.0)$ & $0.7(0.0)$ & $0.7(0.0)$ & $0.7(0.0)$ \\
\hline$T_{3}$ & $12.3(152.2)$ & $7.9(61.3)$ & $6.3(39.2)$ & $6.5(41.3)$ & $3.4(11.2)$ & $3.4(11)$ \\
\hline $\mathbf{T}_{4}$ & $12.3(149.9)$ & $8.0(62.6)$ & $5.3(27.2)$ & $6.2(38.1)$ & $3.7(13.4)$ & $3.5(11.4)$ \\
\hline$T_{5}$ & $10.8(116.2)$ & $7.3(53.4)$ & $5.4(28.7)$ & $6.0(35.6)$ & $3.0(8.7)$ & $3.3(10.1)$ \\
\hline$T_{6}$ & $12.7(160.6)$ & $8.6(73.4)$ & $5.8(33.4)$ & $6.8(46.2)$ & $3.6(12.5)$ & $3.5(12.1)$ \\
\hline $\mathbf{T}_{7}$ & $11.8(139.5)$ & $7.5(55.3)$ & $5.3(27.8)$ & $6.2(38.3)$ & 2.8(7.6) & $3.3(10.6)$ \\
\hline $\mathbf{T}_{8}$ & $12.1(145.8)$ & $8.2(66.1)$ & $5.6(30.7)$ & $6.4(40.7)$ & $3.4(10.7)$ & $3.3(10.6)$ \\
\hline$T_{9}$ & $9.8(95.9)$ & 7.4(38.8) & $5.2(26.7)$ & $4.8(23.1)$ & $2.7(6.9)$ & $2.8(7.3)$ \\
\hline$T_{10}$ & $8.6(73.5)$ & $7.2(51.6)$ & $4.3(17.6)$ & $4.4(18.6)$ & $2.3(4.7)$ & $2.4(5.4)$ \\
\hline $\begin{array}{c}\text { CD } \\
(p=0.05)\end{array}$ & 0.1 & 0.1 & 0.2 & 0.2 & 0.5 & 0.0 \\
\hline
\end{tabular}

The data were transformed before statistical analysis using square root transformation $[\sqrt{x}+0.5]$. Figures in parenthesis are the original value for respective data. 


\section{Effect on yield}

\section{Maize}

During both the years, it was observed that highest maize grain yield and cob yield was obtained in weed free check. Among the weed control treatments, sequential application of atrazine @ $1.5 \mathrm{~kg}$ a.i/ha fb tembortrion@ 120 $\mathrm{g}$ a.i/ha recorded higher maize grain yield (3969 kg/ha and $11529 \mathrm{~kg} / \mathrm{ha}$ in 2015 and 2016, respectively) which was statistically at par with $\mathrm{T}_{9}$ treatment [pre-emergence application of Pendimethalin (1000 ml a.i/ha) $\mathrm{fb}$ Atrazine (750 g a.i/ha) + 2,4-D Amine (400 $\mathrm{ml}$ a.i/ha) at $25 \mathrm{DAS}$ as POE]. The higher grain and cob yield in these treatments could be attributed to improved yield components such as higher number of grains cob- ${ }^{1}$, higher grain row cob- ${ }^{1}$, higher grain weight cob- ${ }^{1}$ and 100 grain weight. Thus, the improvement in yield component was as a consequence of lower crop-weed competition, which shifted the balance in favour of crop in the utilization of nutrients, moisture, light and space. The results are supported with the findings of Angiras (1998) and Kamble et al., (2005).

\section{Wheat}

During the first year (2015-16) of experimentation lower yield of maize was obtain ranging from $2525 \mathrm{~kg} / \mathrm{ha}$ in weedy check to $4135 \mathrm{~kg} / \mathrm{ha}$ in weed free plots along with low yield of succeeding wheat ranging from $144.3 \mathrm{~kg} / \mathrm{ha}$ in weedy check to 3011.3 $\mathrm{kg} / \mathrm{ha}$ in weed free check. This is may be due to low nutrient availability of soil that depleted by the kharif maize.

During the second year (2016-17) of experimentation higher yield of wheat was obtained ranging from $3445.67 \mathrm{~kg} / \mathrm{ha}$ in weedy check to $6031.00 \mathrm{~kg} / \mathrm{ha}$ in weed free check and $\mathrm{T}_{10}$ treatment also recorded higher wheat yield $(5463 \mathrm{~kg} / \mathrm{ha})$. This is might be due to positive residual effect of applied nutrient of preceding kharif maize in cropping system.

\section{System productivity}

During both the year of experimentation highest system productivity $(76092.2 \mathrm{~kg} / \mathrm{ha})$ was revealed in weed free plots which was statistically at par with treatment $\mathrm{T}_{10}(7030.6$ $\mathrm{kg} / \mathrm{ha}$ ) during first year of experimentation and which was closely followed by treatment $\mathrm{T}_{10}(15623.33 \mathrm{~kg} / \mathrm{ha})$ during second year of experimentation. This is mainly due to higher grain yield of both maize and wheat that attributed by lower crop-weed competition along with improved growth and yield components in weed free check and in treatment $\mathrm{T}_{10}$ which receiving atrazine @ 1.5 $\mathrm{kg}$ a.i/ha fb tembortrion $120 \mathrm{~g}$ a.i/ha as POE (Sreenivas and Satyanarayana, 1994).

\section{Economies}

From the data of net return and B: $\mathrm{C}$ ratio showed that there was significant variation in the net return and $\mathrm{B}$ : $\mathrm{C}$ ratio produced in maize-wheat system due to direct and residual effect of different weed control treatments. During the first year of experimentation (2015-16) highest net return and B: C ratio was obtained in treatment $\mathrm{T}_{9}$ which was at par with $\mathrm{T}_{10}$ treatment. During second year of experimentation (2016-17) highest net return (100043/-) was recorded in weed free check followed by sequential application of Atrazine @ $1.5 \mathrm{~kg}$ a.i/ha fb Laudis $120 \mathrm{~g}$ a.i/ha as POE application (RS. 96,452/-). This was due to higher gross return, lower cost of cultivation and higher economic yield of maize (Table 2).

From the above study, it can be concluded that hand weeding, though an effective operation, it is time consuming and labour intensive, expensive, impractical to perform under odd soil condition and at early 
vegetative stages. So, sequential application of Atrazine @ $1.5 \mathrm{~kg} \mathrm{a.i} / \mathrm{ha}$ as pre-emergence fb Tembotrion @120 g a.i/ha as post emergence application in maize-wheat system in New Alluvial zone during kharif will not only increased productivity, net return but also providing an option of economical weed management.

\section{References}

Gomez, K. A. and Gomez, A.A. 1984. Statistical Procedure for Agricultural Research, $2^{\text {nd }}$ Edn. Wiley Inter Science, New York, USA, 680 pp.

Jat, R. K., Gopar, R. and Gupta, R. 2012. Conservation agricultural in maizewheat cropping systems of eastern India: Weed dynamics and system productivity. In: Extended summaries vol. $3,3^{\text {rd }}$ International Agronomy Congress, November 26-30, 2012, New Delhi, India.

Kamble, T. C., Kakade, S. U., Nemade, S.U., Pawar, R. V. and Apotikar, V. A., 2005, A integrated weed management in hybrid maize. Crop Res., Hisar, 29 (3): 396-400.

Kumar, S., Rana, S. S, Chande n. and Angiras, N. N. 2012. Management of hardy weeds in maize under mid-hill conditions of Himachal Pradesh. Indian Journal of Weed Science. 44 (1):11-17.
Ramesh, G., Nadanassababady, T., 2005. Impact of herbicides on weeds and soil ecosystem of rainfed maize (Zea mays L.) Indian J. Agric. Res. 39(1): 31-36.

Saini, J.P. and Angiras, N. N. 1998. Efficacy of herbicides alone and in mixture to control weeds in maize under mid-hill conditions of Himachal Pradesh. Indian J. weed Sci. 30(1/2):65-68.

Singh, A. K., Parihar, C. M., Jat, S. L., Singh, B. and Sharma, S. 2015. Weed management strategies in maize (Zea mays): Effect on weed dynamics, productivity and economies of maizewheat (Triticum aestivum) cropping system in Indogangatic plains. Indian Journal of Agricultural sciences. 85 (1):87-92.

Singh, V. P., Guru, S. K., Kumar, A., Banga, A. and Tripathi, N. 2012. Bio efficacy of tembotrion against mixed weed complex in maize. Indian journal of weed Science. 44. (1); 1-5.

Sreenivas, G. and Satyanarayana, V. 1994. Nutrient removal by weeds and maize (Zea mays). Indian J. Agron. 41(1): 160-162.

Tripathi, A. K, Tewari, A. N. and Prasad, A. 2005. Integrated weed management in rainy season maize (Zea mays L.) in Central Uttar Pradesh. Indian Journal of weed science. 37 (3 \& 4): 269-270.

\section{How to cite this article:}

Sonali Biswas, Srabani Debnath, Abhijit Saha and Benukar Biswas. 2018. Weed Management in Maize System in New Alluvial Zone of West Bengal, India. Int.J.Curr.Microbiol.App.Sci. 7(04): 1344-1350. doi: https://doi.org/10.20546/ijcmas.2018.704.150 